\title{
Food sources of the infaunal suspension-feeding bivalve Cerastoderma edule in a muddy sandflat of Marennes-Oléron Bay, as determined by analyses of carbon and nitrogen stable isotopes
}

\author{
C. K. Kang*, P.-G. Sauriau**, P. Richard, G. F. Blanchard \\ Centre de Recherche en Écologie Marine et Aquaculture de L'Houmeau, CNRS-IFREMER UMR10, BP 5, 17137 L'Houmeau, France
}

\begin{abstract}
Stable carbon and nitrogen isotope ratios were used to define the trophic base of the infaunal suspension-feeding bivalve Cerastoderma edule (L.) living on an intertidal muddy sandflat in Marennes-Oléron Bay, France. Suspended particulate organic matter (POM) collected from adjacent marine channels had a mean $\delta^{13} \mathrm{C}$ value of $-22.2 \pm 1.1 \%$ o $(\mathrm{n}=19)$. Benthic primary producers on Ronceles-Bains tidal flats had $\delta^{13} \mathrm{C}$ values distinct from that of the POM: microphytobenthos $(-16.0 \pm 0.6 \%)$, the macroalgae Enteromorpha compressa $(-17.6 \pm 2.8 \%$ ), Fucus serratus $(-17.4 \pm 2.6 \%)$, Fucus vesiculosus $(-18.5 \pm 1.6 \%)$, Phorphyra umbilicalis $(-19.7 \pm 0.5 \%)$, Ulva rigida $(-14.7 \pm 2.0 \%)$ and the seagrass Zostera noltii $(-11.1 \pm 1.0 \%)$. Mean $\delta^{15} \mathrm{~N}$ values of all macroalgae species ranged from $7.6 \pm 1.3$ to $8.9 \pm$ $1.0 \%$, while those for microphytobenthos, POM and seagrass were $5.3 \pm 0.8,5.0 \pm 0.9$ and $6.5 \pm 1.3 \%$, respectively. The mean $\delta^{13} \mathrm{C}$ value of spat $(-15.3 \pm 0.8 \%$ ) and juvenile cockles $(-15.7 \pm 0.7 \%$ varied within a smaller range than those of 1 to 4 yr old adults $(-18.2 \pm 1.2 \%)$. The $\delta^{15} \mathrm{~N}$ values of 0 -group cockles (spat and juveniles) and adult cockles are similar ( $8.0 \pm 0.9 \%$ for 0 -group and $8.4 \pm 1.1 \%$ for adults). The results suggest, based on the average trophic enrichment found in the literature for $\mathrm{C}$ and $N$, and the relative abundance of each food source, that there are 2 major sources of organic matter assimilated by cockles of the studied flats: microphytobenthos and POM. Seasonal variations in $\delta^{13} \mathrm{C}$ values reflect a higher dependence of adult cockles on POM variability while spat and juveniles are more closely linked to microphytobenthos. The isotopic shifts indicate that the relative importance of the 2 major food sources depends on the age of the cockles and the season.
\end{abstract}

KEY WORDS: Stable isotope ratios $\cdot$ Particulate organic matter $\cdot$ Microphytobenthos $\cdot$ Cerastoderma edule - Suspension feeder

\section{INTRODUCTION}

The common cockle Cerastoderma edule (L.) is an inhabitant of sandy tidal flat areas along the Northwest European coasts and estuaries and is an infaunal suspension feeder. In this respect, long-standing dogma is that suspension-feeding organisms are subjected to variable and unpredictable food supplies compared to

\footnotetext{
- Present address: National Fisheries Research \& Development Institute (Pohang Regional Laboratory), 616 Duhodong, Buk-gu, Pohang 791-110, South Korea

- Addressee for correspondence.

E-mail: pierre.guy.sauriau@ifremer.fr
}

deposit-feeding organisms, which experience a more constant food supply (Levinton 1972), and that phytoplankton is a major component of their diet (Purchon 1977). For example, in a dense population of $C$. edule, Loo \& Rosenberg (1989) showed that this species, along with Mya arenaria (L.), made a significant impact on the phytoplankton biomass in Laholm Bay of the Kattegat. Such a benthic-pelagic coupling between benthic suspension feeders and phytoplankton has also been reported on a larger scale for San Francisco Bay (Cloern 1982, Nichols 1985), for estuaries in North Carolina (Officer et al. 1982) and is to date a well documented phenomenon (Dame 1996). Coastal and estuarine habitats are also characterised by high seston 
loads and variable ratios of organic versus inorganic materials. Physiological studies on the feeding behavjour of $C$. edule have demonstrated that this species is particularly well adapted to these habitats (Prins et al. 1991, Iglesias et al. 1992, Navarro et al. 1992, Navarro \& Widdows 1997). C. edule is able to regulate both its clearance rate and pseudofeces production in response to high seston concentrations. These studies also found experimental evidence for a preferential ingestion of algal components (i.e. Tetraselmis sp. cells) by C. edule relative to other silty components (Iglesias et al. 1992). Ingestion experiments using natural sediments also determined that cockles had a constant sorting efficiency for organic matter over a broad range of seston concentrations between 5 and $100 \mathrm{mg} \mathrm{l}^{-1}$ (Navarro et al. 1992), which then declined to lower values at higher seston concentrations (Navarro \& Widdows 1997). It has also been documented that $C$. edule ingests other materials such as benthic algae, sand grains, bivalve larvae and foraminifers (see Ivell 1981 and references therein). A recent study conducted by Kamermans (1994) in the Wadden Sea (The Netherlands) indicated that gut contents of both suspension feeders ( $C$. edule) and deposit feeders [such as Macoma balthica (L.) and Scrobicularia plana (da Costa) that are known to be facultative suspension feeders] showed a higher correlation with the benthic algal composition of water samples taken close to the bottom than with the benthic algal composition of sediment samples. This supports the conclusion given by de Jonge \& van Beusekom (1992) that the availability of benthic algal sources for filter feeders is linked to the resuspension of sediments by wind-driven waves acting on large intertidal flats, and by tidal currents.

Determination of the relative proportion of various food sources assimilated by filter feeders is an important question in understanding their feeding physiology and food base induced by benthic-pelagic coupling processes. Gut content analyses however provide only rough estimates of the percentages of various materials ingested by cockles and may reflect material that is not assimilated. When components of the food are digested quickly, estimates of their relative proportions are impossible. In this respect, considerable interest has been taken in the use of stable isotope analysis to identify the source of food actually assimilated by estuarine bivalve molluscs (Incze et al. 1982, Stephenson \& Lyon 1982, Riera \& Richard 1996). Application of this technique to food web studies is based upon the fact that stable isotope compositions of an animal are generally determined by the composition of its food (see reviews by Fry \& Sherr 1984, Michener \& Schell 1994). Though there is a trend of enrichment in heavier isotopes with increasing trophic level, such metabolic isotopic fractionations occurring within animal bodies are measurable and predictable (DeNiro \& Epstein 1978, 1981, Rau et al. 1983). However, when the stable isotope ratios of primary food resources overlap (Schwinghamer et al. 1983, Riera \& Richard 1996) or when there are 3 or more potential food sources, using stable isotopes of a single element such as carbon makes it difficult to identify food sources for consumers. In these cases, a dual isotope approach, for example, carbon and nitrogen, provides more precise information (Peterson \& Howarth 1987, Currin et al. 1995).

The primary objective of this study was to seasonally assess the assimilated food sources of the common cockle Cerastoderma edule living on intertidal sandflats of Marennes-Oléron Bay, France, based on the dual stable isotopic $\left(\delta^{13} \mathrm{C}\right.$ and $\left.\delta^{15} \mathrm{~N}\right)$ analyses of animals and their potential food resources. In a broad tidal flat of turbid coastal embayment, such as MarennesOléron Bay, seston dynamics are strongly influenced by advection of different water masses (Bacher 1989) and by wind-and tide-induced resuspension of sediment (Héral et al. 1987, Prou et al. 1994). Autochthonous primary production of phytoplankton in the Marennes-Oléron Bay is highly limited due to the high turbidity of the water column (Raillard \& Ménesguen 1994). A considerable amount of chlorophyll $a$ in the water column is therefore accounted for by resuspended microphytobenthos, mainly benthic diatoms (Prou et al. 1994, Zurburg et al. 1994). Additionally, terrestrial particulate organic matter (POM) and benthic macroalgae can contribute to the organic matter pool of the Marennes-Oléron Bay system (Feuillet-Girard et al. 1994, Richard et al. 1997). However, it was shown that incorporation by oysters of terrestrial sources of organic matter is limited to the high flood season and to particular habitats in the vicinity of the Charente estuary (Riera \& Richard 1996, 1997). Geological and sedimentological maps given by Papy (1941) and Sauriau et al. (1989) also indicated that rocky shores are scarce, and that silt and clay components are dominant in bottom sediments over the whole bay. This explains, along with the high turbid coastal environment, the scarcity of macroalgae biomasses within the bay as confirmed by the use of high resolution satellite imaging (Guillaumont 1991). Therefore, taking such environmental characteristics of Marennes-Oléron Bay into consideration, our hypothesis was that microphytobenthos is a major food source for endofaunal cockles in this particular habitat, which is dominated by highly turbid waters.

\section{MATERIALS AND METHODS}

Study area. This study was carried out on the intertidal muddy sandflat of Ronce-les-Bains, at the south- 


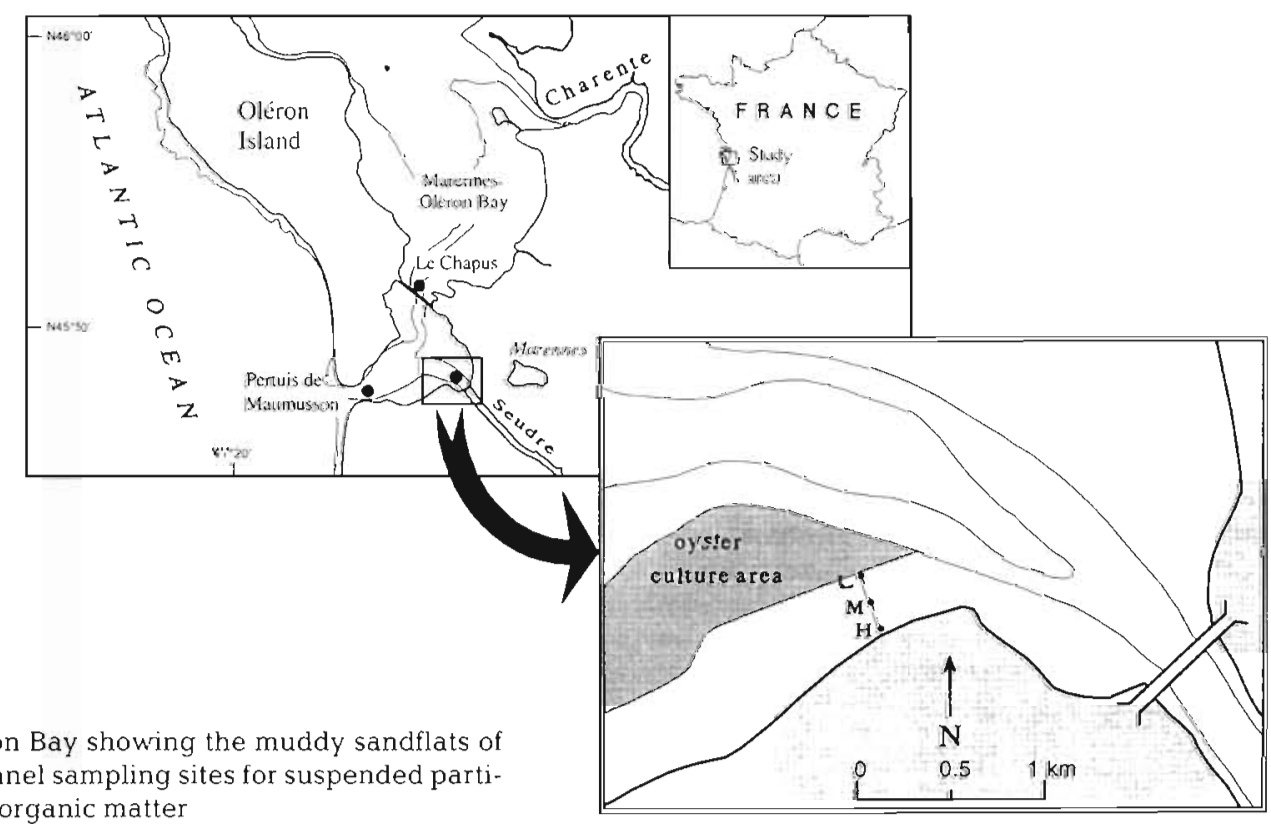

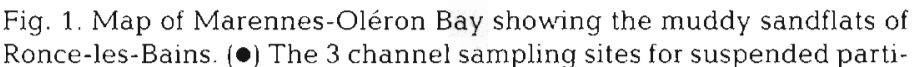
culate organic matter

ern end of Marennes-Oléron Bay (Fig. 1). The tides are semi-diurnal with a maximal range of $6.5 \mathrm{~m}$. The local strong tidal current regime leads to well-mixed and highly turbid waters. Oceanic waters enter through the north entrance (Pertuis d'Antioche) and move south through the central water channel and, to a lesser extent, are introduced through the south-west entrance (Pertuis de Maumusson) close to Ronce-lesBains flats. Freshwater flows into the bay mainly from the Charente River that drains $>4 \times 10^{3} \mathrm{~km}^{2}$ of agricultural and forested land. The studied flat belongs to the Seudre River, which provides a relatively weak input of freshwater, because the Seudre salt-marsh system is used for oyster refining (Grelon 1978). However, during years of high freshwater discharge $(>1500$ to $2000 \mathrm{~m}^{3} \mathrm{~s}^{-1}$ ) of the Gironde river, located south of Marennes-Oléron Bay, and when western winds are dominant, waters from the Gironde estuary plume can influence Marennes-Oléron Bay (Fontugne \& Jouanneau 1987, Lazure \& Jégou 1998).

At the upper and middle part of the tidal flat in Ronce-les-Bains, the sediment is dominated by fine sand with ca $1 \%$ of organic matter content (determined by loss of weight of dried sediment sample on ignition at $450^{\circ} \mathrm{C}$ ). Mean cockle density was $261 \pm$ 277 ind. $\mathrm{m}^{-2}$ in 1995. In the lower flat, the sediment is composed of muddy sand with ca $2.6 \%$ organic matter and combined silt and clay contents of ca $23 \%$. Cockles were scarce $\left(35 \pm 36\right.$ ind. $\left.\mathrm{m}^{-2}\right)$ at the lower part of the flat in 1995. Near the low-water line, which is occupied by extensive oyster-culture beds, the substratum becomes muddier. Dominant macrozoobenthic species are Abra tenuis (Montagu), Ampharete acutifrons
(Grube), Aphelochaeta (Tharyx) marioni (de SaintJoseph), Arenicola marina (L.), Hydrobia ulvae (Pennant), Carcinus maenas (L.), Cerastoderma edule, Nephtys hombergii Savigny, Notomastus latericeus M. Sars and Scoloplos armiger (O. F. Müller) on Ronceles-Bains flat (de Montaudouin pers, comm.).

Average microphytobenthic biomasses were estimated to be from 120 (June 1995) to $85 \mathrm{mg} \mathrm{chl} \mathrm{a} \mathrm{m}^{-2}$ (January 1996) by Guarini et al. (1998); these values were among the highest figures recorded within the bay of Marennes-Oléron. Although the bay is surrounded by wide areas $\left(110 \mathrm{~km}^{2}\right)$ of salt marshes, these marshes are entirely managed with marine waters, and used for oyster culture and refining (see for details the synopses of Korringa 1976 and Grelon 1978). Thus the salt marshes lining the bay do not play a significant role in the input of terrestrial organic matter to Marennes-Oléron Bay (Richard et al. 1997, Riera \& Richard 1997).

Sample collection and preparation. Cockles were collected seasonally in 1995 (March, June, September and December). The cockles were kept alive overnight in filtered water from the sampling site to evacuate gut contents. Each analysed sample consisted of 2 to 5 individuals pooled by size (adults and juveniles) and 10 to 20 individuals for September and June recruitment, respectively.

To determine the isotopic value for POM introduced to the flat through the water channel, spring- and neap-tide samplings were conducted seasonally at 3 stations: Maumusson, Seudre river mouth and Le Chapus (Fig. 1). About $20 \mathrm{l}$ of water was pumped and prefiltered with a $63 \mu \mathrm{m}$ screen to remove any zooplank- 
ton and then POM was filtered on precombusted Whatmann $\mathrm{GF} / \mathrm{F}$ filters and the filtrates were rinsed 3 times with Milli-Q water.

Macroalgae and seagrass (Zostera noltii Hornem) samples were collected by hand at each cockle sample time when the flat was exposed. Macroalgae were collected from the oyster-culturing tables near the water channel of the intertidal flat of Ronce-les-Bains coast and Oléron Island. All samples were acidified in $10 \% \mathrm{v}: \mathrm{v} \mathrm{HCl}$ to remove salts and carbonates, quickly rinsed twice with Milli-Q water, freeze-dried, ground to a fine powder and kept frozen $\left(-80^{\circ} \mathrm{C}\right)$ until analysis. Procedures for chlorophyll and particulate organic carbon analyses were as previously described by Richard et al. (1997).

Stable isotope analyses. Samples for isotope analyses were prepared as described by Boutton (1991). Before the purification of $\mathrm{CO}_{2}, \mathrm{~N}_{2}$ was trapped on silica gel granules in a stopcock sample ampoule and analysed immediately after $\mathrm{CO}_{2}$ collection (Mariotti 1982). The carbon and nitrogen isotope ratios were measured using a Sigma 200 (CJS Sciences, Winsford, England) double inlet, triple collector isotope ratio mass spectrometer. Data were expressed in the standard $\delta$ unit notation where $\delta X=\left[\left(R_{\text {sample }} / R_{\text {reference }}\right)-1\right]$ $\times 10^{3}$, where $R={ }^{13} \mathrm{C} /{ }^{12} \mathrm{C}$ for carbon and ${ }^{15} \mathrm{~N} /{ }^{14} \mathrm{~N}$ for nitrogen, and reported relative to the Pee Dee Belemnite standard for carbon and to atmospheric $\mathrm{N}_{2}$ for nitrogen. The typical precision of the overall procedure (i.e. preparation plus analysis) was $\pm 0.1 \%$ for carbon and $\pm 0.2 \%$ for nitrogen.

Statistical comparisons. Due to the low number of stable isotope analyses, most of the sample comparisons were done using non parametric methods, since these methods are not dependent on a given distribution and variance levels (Sokal \& Rohlf 1981). The Kruskal-Wallis test was used to test the null hypothesis that different samples come from populations having the same $\delta^{13} \mathrm{C}$ and/or $\delta^{15} \mathrm{~N}$. However, in the case of 3 samples with sizes less than 5, the Kruskal-Wallis statistic does not follow the chi-square distribution. The exact distribution table given by Siegel (1956, p. 282-283) was used.

\section{RESULTS}

\section{Abundance of potential food sources}

Salinity ranged from $25.7 \%$ in March 1995 to $34.7 \%$ in September 1995 (Table 1). The chlorophyll a concentration and chlorophyll a/phaeopigment ratio in the water column peaked in June 1995, when the mean values were $3.71 \pm 1.68 \mu \mathrm{g} \mathrm{l}^{-1}$ and 0.76 , respectively, indicating the spring phytoplankton bloom. The ratio of organic carbon/chlorophyll $a$ is indicative of the detrital content of POM. Ratios of less than 100 indicate that much of the particulate organic carbon (POC) derives from a living source such as algae (Berg \& Newell, 1986). Carbon/chlorophyll a ratios were persistently high (293 to 1762), although a comparatively low ratio was observed in June, consistent with increased relative algal inputs. The generally high ratios indicate that detrital materials, including resuspended oyster biodeposits, were always a major constituent of POM in the bay. Feuillet-Girard et al. (1994) also indicated from POM and sediment samples taken from the centre of Marennes-Oléron Bay in 1979-1980 that more than $80 \%$ of POC originated from detrital material. However, winter POC within the bay included less than $20 \%$ of terrestrial organic matter as determined by stable carbon analyses (Feuillet-Girard et al. 1994).

In contrast, the chlorophyll a content in the sediment organic matter (SOM) of the studied flat was relatively constant with season (Table 1). Generally, high chlorophyll a/phaeopigment ratios (1.21 to 2.98$)$ indicate high activities of living algae. In addition, much lower carbon/chlorophyll a ratios in SOM than in the water column indicate that considerable amounts of microphytobenthos may exist throughout the year.

Several macroalgal species such as Enteromorpha compressa Greville, Fucus serratus L., Fucus vesiculosus L., Porphyra umbilicalis L., Ulva rigida Agardh. Chondria dasyphylla (Woodward) occur on Ronce-lesBains flats. However, these species are mainly located on the lowest part of the flats within oyster parks. Thus,

Table 1. Salinity, particulate organic matter (POM) and sediment organic matter (SOM) characteristics in Marennes-Oléron Bay in 1995. Each value is the mean of 6,6 and 9 samples for salinity, POM and SOM, respectively

\begin{tabular}{|c|c|c|c|c|c|c|c|}
\hline \multirow[t]{2}{*}{ Month } & \multirow{2}{*}{$\begin{array}{c}\text { Salinity } \\
\text { (Maumusson, } \\
\text { Seudre, } \\
\text { Le Chapus) }\end{array}$} & \multicolumn{3}{|c|}{$\begin{array}{c}\text { POM } \\
\text { (Maumusson, Seudre, Le Chapus) }\end{array}$} & \multicolumn{3}{|c|}{$\begin{array}{c}\text { SOM } \\
\text { (Ronce-les-Bains) }\end{array}$} \\
\hline & & $\begin{array}{c}\text { Chl } a \\
\left(\mu \mathrm{gl}^{-1}\right)\end{array}$ & $\begin{array}{l}\text { Chl a/ } \\
\text { phaeopigment }\end{array}$ & POC/chl a & $\begin{array}{c}\text { Chl a } \\
\left(\mu g^{-1} \text { dry sed. }\right)\end{array}$ & $\begin{array}{c}\text { Chl a/ } \\
\text { phaeopigment }\end{array}$ & $\mathrm{POC} / \mathrm{chl} a$ \\
\hline Mar & $25.7 \pm 2.3$ & $0.80 \pm 0.18$ & $0.49 \pm 0.17$ & $1577 \pm 937$ & $12.90 \pm 4.60$ & $2.98 \pm 2.41$ & $191 \pm 127$ \\
\hline Jun & $31.9 \pm 0.9$ & $3.71 \pm 1.68$ & $0.76 \pm 0.19$ & $293 \pm 81$ & $9.33 \pm 2.43$ & $1.35 \pm 0.82$ & $179 \pm 90$ \\
\hline Sep & $34.7 \pm 0.2$ & $0.94 \pm 0.29$ & $0.43 \pm 0.10$ & $648 \pm 61$ & $11.64 \pm 3.29$ & $1.21 \pm 0.56$ & $151 \pm 20$ \\
\hline Dec & $32.4 \pm 0.5$ & $0.53 \pm 0.16$ & $0.19 \pm 0.09$ & $1762 \pm 669$ & $9.83 \pm 2.96$ & $1.37 \pm 0.76$ & $256 \pm 85$ \\
\hline
\end{tabular}


the surface area covered by these macroalgae accounts for about 3 to $5 \%$ of the 50 ha cockle bed. Very few Zostera noltii spots $\left(<0.1 \mathrm{~m}^{2}\right)$ were also found in 1995 and they accounted for less than $1 / 10000$ of the cockle bed area.

\section{Isotopic compositions of potential food sources}

The carbon and nitrogen isotope compositions of benthic primary producers and POM within the bay system are summarised in Table 2. Isotopic compositions of POM were determined for seston from 3 water channels (Maumusson, Seudre and Le Chapus) near the studied flat. POM had quite constant $\delta^{13} \mathrm{C}$ values of $-22.4 \pm 0.1 \%$ (December 1995) to $-21.6 \pm 0.6 \%$ (September 1995$)$, with a mean $\delta^{13} \mathrm{C}$ of $-22.2 \pm 1.1 \%$ for all 19 POM samples. The $\delta^{15} \mathrm{~N}$ values of POM ranged from $4.5 \pm 1.4 \%$ (March 1995 ) to $5.6 \pm 0.1 \%$ (June 1995), with a mean $\delta^{15} \mathrm{~N}$ of $5.0 \pm 0.9 \%$ for all 18 samples. Therefore, the isotopic values of POM were not significantly different among the sampling months and the sampling stations (2-way ANOVA for unbalanced data with fixed factors 'month' and 'station' and without test of interaction; for both factors, $\mathrm{p}>0.6$ and $\mathrm{p}>0.1$ for $\delta^{13} \mathrm{C}$ and $\delta^{15} \mathrm{~N}$ data, respectively). Isotopic values fall within the ranges obtained from the northern part of the bay in 1992-1993 (Riera \& Richard 1996, Riera et al. 1996, Riera 1998) and the central part of the bay in 1979-1980 (Feuillet-Girard et al. 1994).

Macroalgae showed a relatively wide range of $\delta^{13} \mathrm{C}$ values from $-20.1 \%$ (Fucus vesiculosus, March 1995) to $-11.1 \%$ (Ulva rigida, December 1995). There were no significant differences for the $\delta^{13} \mathrm{C}$ values between macroalgal species (Kruskal-Wallis test, $\mathrm{p}=0.19$ ) due to variability of $\delta^{13} \mathrm{C}$ values in $F$. serratus. A mean $\delta^{13} \mathrm{C}$ value for $U$. rigida $(-14.7 \pm 2.0 \%)$ was however much more positive than those of the other macroalgae, except $\delta^{13} \mathrm{C}$ values for $F$. serratus in June 1995. This trend is similar to the distribution of macroalgae $\delta^{13} \mathrm{C}$ values found at the marine littoral site of Ré Island and at the northern mudflat of the bay by Riera \& Richard (1996) and Riera et al. (1996). Such a wide range of $\delta^{13} \mathrm{C}$ values has also been reported by several other authors (see Kerby \& Raven 1985, Currin et al. 1995). The $\delta^{15} \mathrm{~N}$ values of macroalgae exhibited no significant difference between species (Kruskal-Wallis test, p > 0.15 ) with a mean global value of $8.2 \pm 1.3 \%$. These values were similar to $\delta^{15} \mathrm{~N}$ values from the northern mudflats of the bay (Riera 1998) and those found in the literature (see Currin et al. 1995).

Seagrass Zostera noltii had a quite narrow range of $\delta^{13} \mathrm{C}$ values from $-12.1 \pm 1.0 \%$ (March 1995 ) to $-10.3 \%$ (September 1995). $\delta^{15} \mathrm{~N}$ values varied from $5.7 \pm 0.4 \%$ (March 1995) to $8.7 \%$ (September 1995), with no significant difference among the sampling dates

Table 2. $\delta^{13} \mathrm{C}$ and $\delta^{15} \mathrm{~N}$ data for samples of cockles Cerastoderma edule and potential food resources collected in MarennesOléron Bay in 1995. Values indicate mean $\pm 1 \mathrm{SD}$. Values in parentheses represent the number of analysed samples of pooled individuals. In the case of $C$. edule, pools of 2,5 and 20 individuals for adults, juveniles and spat were used, respectively

\begin{tabular}{|c|c|c|c|c|c|c|c|c|}
\hline \multirow{2}{*}{ Sample } & \multicolumn{4}{|c|}{$\delta^{13} \mathrm{C}\left(\%_{0}\right)$} & \multicolumn{4}{|c|}{$\delta^{15} N(\%)$} \\
\hline & Mar & Jun & Sep & Dec & Mar & Jun & Sep & Dec \\
\hline \multicolumn{9}{|l|}{ Cerastoderma edule } \\
\hline $\begin{array}{l}\text { Adults } \\
\quad(\text { size }>12 \mathrm{~mm})\end{array}$ & $\begin{array}{c}-19.1 \pm 0.9 \\
(7)\end{array}$ & $\begin{array}{c}-17.7 \pm 1.1 \\
(11)\end{array}$ & $\begin{array}{l}-17.5 \pm 0.8 \\
(5)\end{array}$ & $\begin{array}{c}-17.2 \pm 0.7 \\
(4)\end{array}$ & $\begin{array}{c}8.0 \pm 0.5 \\
(7)\end{array}$ & $\begin{array}{l}7.6 \pm 0.8 \\
(11)\end{array}$ & $\begin{array}{c}7.7 \pm 1.0 \\
(5)\end{array}$ & $\begin{array}{c}9.3 \pm 1.9 \\
(4)\end{array}$ \\
\hline $\begin{array}{l}\text { Juveniles } \\
\qquad(5<\text { size } \leq 12 \mathrm{~mm})\end{array}$ & - & - & $\begin{array}{c}-15.7 \pm 0.7 \\
(3)\end{array}$ & $\begin{array}{c}-15.7 \pm 0.2 \\
(4)\end{array}$ & - & - & $\begin{array}{c}8.7 \pm 0.8 \\
(3)\end{array}$ & $\begin{array}{c}8.8 \pm 1.2 \\
(4)\end{array}$ \\
\hline $\begin{array}{l}\text { Spat } \\
\quad \text { (size } \leq 5 \mathrm{~mm})\end{array}$ & - & $\begin{array}{l}-14.3 \pm 1.0 \\
\text { (4) }\end{array}$ & $\begin{array}{c}-15.8 \pm 0.4 \\
(2)\end{array}$ & - & - & $\begin{array}{l}7.6 \pm 0.8 \\
(4)\end{array}$ & $\begin{array}{c}7.8 \pm 0.6 \\
(2)\end{array}$ & - \\
\hline Fucus serratus & $\begin{array}{c}-20.0 \pm 0.2 \\
(2)\end{array}$ & $\begin{array}{c}-14.4 \pm 0.1 \\
(2)\end{array}$ & $\begin{array}{c}-16.9 \\
(1)\end{array}$ & $\begin{array}{l}-18.8 \\
(1)\end{array}$ & $\begin{array}{c}7.6 \pm 1.4 \\
(4)\end{array}$ & $\begin{array}{c}8.1 \pm 1.9 \\
(2)\end{array}$ & $\begin{array}{l}8.1 \\
\text { (1) }\end{array}$ & $\begin{array}{l}6.9 \\
(1)\end{array}$ \\
\hline Fucus vesiculosus & $\begin{array}{c}-20.1 \\
(1)\end{array}$ & - & $\begin{array}{c}-16.9 \\
\text { (1) }\end{array}$ & $\begin{array}{c}-18.5 \\
(1)\end{array}$ & $\begin{array}{l}8.6 \\
(1)\end{array}$ & - & $\begin{array}{l}8.4 \\
(1)\end{array}$ & $\begin{array}{l}7.8 \\
(1)\end{array}$ \\
\hline Ulva rigida & $\begin{array}{c}-15.0 \\
(1)\end{array}$ & $\begin{array}{l}-15.8 \\
(1)\end{array}$ & $\begin{array}{l}-15.9 \pm 0.1 \\
(2)\end{array}$ & $\begin{array}{l}-11.1 \\
(1)\end{array}$ & $\begin{array}{l}8.9 \\
(1)\end{array}$ & $\begin{array}{l}9.0 \\
(1)\end{array}$ & $\begin{array}{l}8.1 \pm 0.1 \\
(2)\end{array}$ & $\begin{array}{c}10.6 \\
(1)\end{array}$ \\
\hline Porphyra umbilicalis & - & - & $\begin{array}{c}-19.7 \pm 0.5 \\
(2)\end{array}$ & - & - & - & $\begin{array}{l}8.4 \pm 0.5 \\
(2)\end{array}$ & \\
\hline Enteromorpha compressa & $\begin{array}{l}-15.0 \\
(1)\end{array}$ & $\begin{array}{c}-17.6 \pm 2.8 \\
(2)\end{array}$ & - & - & $\begin{array}{l}8.9 \\
(1)\end{array}$ & $\begin{array}{c}8.2 \pm 1.1 \\
(2)\end{array}$ & - & - \\
\hline Zostera noltii & $\begin{array}{c}-12.1 \pm 1.0 \\
(2)\end{array}$ & $\begin{array}{c}-10.6 \pm 0.4 \\
(2)\end{array}$ & $\begin{array}{c}-10.3 \\
(1)\end{array}$ & - & $\begin{array}{l}5.7 \pm 0.4 \\
\text { (3) }\end{array}$ & $\begin{array}{c}6.7 \pm 0.6 \\
(2)\end{array}$ & $\begin{array}{l}8.7 \\
(1)\end{array}$ & - \\
\hline POM & $\begin{array}{c}-22.3 \pm 2.1 \\
(5)\end{array}$ & $\begin{array}{c}-22.1 \pm 1.2 \\
\text { (5) }\end{array}$ & $\begin{array}{c}-21.6 \pm 0.6 \\
\text { (3) }\end{array}$ & $\begin{array}{c}-22.4 \pm 0.1 \\
(6)\end{array}$ & $\begin{array}{c}4.5 \pm 1.4 \\
(6)\end{array}$ & $\begin{array}{c}5.6 \pm 0.1 \\
\text { (3) }\end{array}$ & $\begin{array}{c}4.9 \pm 0.2 \\
\text { (3) }\end{array}$ & $\begin{array}{c}5.3 \pm 0.4 \\
\text { (6) }\end{array}$ \\
\hline
\end{tabular}


(Kruskal-Wallis test, $\mathrm{p}>0.2$ for $\delta^{13} \mathrm{C}$ and $\mathrm{p}>0.1$ for $\delta^{15} \mathrm{~N}$, p given by an exact distribution table of the Kruskal-Wallis statistic for 3 groups). Isotopic data for this species are quite limited in the literature. The $\delta^{13} \mathrm{C}$ values obtained from the present investigation compare well with those $(-11.6 \pm 0.5 \%)$ determined by McMillan et al. (1980).

\section{Isotopic compositions of cockle tissue}

Samples of cockles sorted and pooled by age class were analysed seasonally (Table 2 ), $\delta^{13} \mathrm{C}$ values for cockles displayed a relatively wide range from $-14.8 \pm$ $1.0 \%$ (spat in June 1995) to $-19.1 \pm 0.9 \%$ (adults, March 1995). This was attributed to the difference between $\delta^{13} \mathrm{C}$ values of spat. (June) and adults, juvenile and spat (September) $\delta^{13} \mathrm{C}$ values being intermediate. The mean $\delta^{13} \mathrm{C}$ value $(-14.8 \pm 1.0 \%)$ of spat in June 1995 was 3 to $3.5 \%$ more positive than that $(-18.0 \pm$ $1.2 \%$ ) of adults ( 1 to 4 age classes). The range in $\delta^{13} \mathrm{C}$ values $(-14.8 \pm 1.0$ to $-15.8 \pm 0.4 \%$ of of the 0 -group was narrower than that $(-17.2 \pm 0.7 \%$ to $-19.1 \pm 0.9 \%)$ of adults. 0 -group cockles had a significant difference in $\delta^{13} \mathrm{C}$ values among the sampling dates (Kruskal-Wallis test, exact distribution table for 3 groups with 4,5 and 4 samples for June, September and December, respectively; $p=0.037$ ), the $\delta^{13} \mathrm{C}$ value of spat in June being significantly lower than other $\delta^{13} \mathrm{C}$ values of the 0 group. Adults showed significant differences in $\delta^{13} \mathrm{C}$ values (Kruskal-Wallis test, $p<0.025$ ). The $\delta^{13} \mathrm{C}$ values for adult cockles from December were about $1.9 \%$ more positive than those of March. $\delta^{15} \mathrm{~N}$ values of cockles fell within a quite narrow range of $7.3 \pm 0.8$ to $9.3 \pm 1.9 \%$, with mean values of $8.0 \pm 0.9 \%$ and $8.4 \pm$ $1.1 \%$ for the 0 -group and adults, respectively. No significant difference was found in the $\delta^{15} \mathrm{~N}$ values between 0-group and adult cockles (Student's $t$-test, $p>0.2$ ) or among the sampling dates (Kruskal-Wallis test, $p=0.07$ and $p=0.24$ for 0 -group and adult cockles, respectively). This was probably due to a positive correlation between $\delta^{15} \mathrm{~N}$ means and variances for the cockle 1995 data set (Table 2).

\section{DISCUSSION}

\section{Stable isotope composition of food sources}

Previous reports on the carbon and nitrogen stable isotope compositions of microphytobenthos, POM, sediment organic matter and macroalgae in MarennesOléron Bay concentrated on the Charente River estuarine system in the northern part of the bay (Riera \& Richard 1996, Richard et al. 1997, Riera 1998). Some $\delta^{13} \mathrm{C}$ values for POM and sediment organic matter (range -20.2 to $-22.5 \%$ ) from oyster parks located in the centre of Marennes-Oléron Bay were also given by Feuillet-Girard et al. (1994). However, the carbon and nitrogen isotope compositions of food components within the southern part of the Marennes-Oléron Bay were newly investigated in this study.

$\delta^{13} \mathrm{C}$ recorded values of POM (Table 2) were included in the range of -18 to $-25 \%$ that encompasses all marine and estuarine POM from surface waters in the latitudinal range 45 to $50^{\circ} \mathrm{N}$ (Goericke et al. 1994). They were also similar to $\delta^{13} \mathrm{C}$ values of POM reported by Fontugne \& Jouanneau (1987) on the continental shelf of the Gulf of Biscay during hydrological surveys made in the Gironde river plume and in the vicinity of the Pertuis de Maumusson (Fig. 1). $\delta^{13} \mathrm{C}$ recorded values of POM $(-22.2 \pm 1.1 \%)$ introduced to the studied flat were within the range of $-23.5 \%$ for estuarine phytoplankton from Marennes-Oléron Bay (Riera \& Richard 1996) to $-20.5 \%$ (range -19.9 to $-21.0 \%$ ) for oceanic phytoplankton as determined by Fontugne \& Jouanneau (1987) from Gulf of Biscay seston samples.

Fluxes of estuarine and coastal POM, especially during high freshwater discharge periods of the Gironde river (Fontugne \& Jouanneau 1987), combined with western winds (Lazure \& Jégou 1998) and fluxes of oceanic phytoplankton, mainly from spring to autumn, are advected through Pertuis de Maumusson, which plays a major part in introducing marine waters in the southern sector of the bay (Fig. 1). Waters of the bay generally move from north to south within a 5 to $10 \mathrm{~d}$ period, and thus the northern waters pass through Pertuis de Maumusson (Bacher 1989) after being advected to Ronce-les-Bains flat during each flood-tide phase. It is therefore reasonable to consider algal inputs to the intertidal flat of Ronce-les-Bains as a simple mixture of coastal and oceanic phytoplankton as indicated by Prou et al. (1994) by means of species composition of pelagic and benthic diatoms at Le Chapus (see Fig. 1). In contrast, in the vicinity of the Charente River estuary, Richard et al. (1997) proved that POM was a complex mixture of various sources such as terrestrial POM $(-27.5 \%$, Riera \& Richard 1996), microphytobenthos $(-16.0 \pm 0.6 \%$, Riera et al. 1996) and macroalgae $(-17.1 \pm 2.5 \%$, this study) along with estuarine and oceanic phytoplankton. Zostera noltii had a mean $\delta^{13} \mathrm{C}$ value of $-11.1 \pm 1.0 \%$ (Table 2 ). Thus, taking the end-member value of estuarine POM and the value of POM introduced to the studied flat into consideration, the contribution of this seagrass to the POM pool would appear to be minor. In addition, we cannot exclude that microphytobenthos contribute to the POM advected to the studied flat (for instance, embedded in suspension-feeder fecal pellets), together with coastal and open sea phytoplankton. 
The $\delta^{13} \mathrm{C}$ values of cockle tissue $(-14.8 \pm 1.0 \%$ for spat in June, $-15.8 \pm 0.4 \%$ for spat in September, $-15.7 \pm$ $0.7 \%$ for juveniles and -19.1 to $-17.2 \%$ for adults) were more positive than those of POM introduced on the studied flat, indicating more incorporation of material more ${ }^{13} \mathrm{C}$-enriched than the estuarine phytoplankton. However, interpreting trophic transfer using the stable carbon isotope ratio alone is complicated by the fact that multiple alternative sources are comparatively ${ }^{13} \mathrm{C}$ enriched and overlap in $\delta^{13} \mathrm{C}$ value. In the present study, the simultaneous use of dual isotopes $\left(\delta^{13} \mathrm{C}\right.$ and $\left.\delta^{15} \mathrm{~N}\right)$ allowed 3 potential food sources to be more easily distinguished: POM, microphybenthos and macroalgae (Fig. 2). POM had $\delta^{13} \mathrm{C}$ values distinct from those of microphytobenthos and macroalgae, whereas mean $\delta^{15} \mathrm{~N}$ values of macroalgae $(7.6 \pm 1.3$ to $8.9 \pm 1.0 \%$ ) were distinct from those of POM $(5.0 \pm 0.9 \%)$ and microphytobenthos $(5.3 \pm 0.8 \%$ ) , as indicated by Riera et al. (1996).

\section{Identification of food source of cockles using the dual isotope approach}

The use of a dual isotope plot (Fig. 2) of $\delta^{13} \mathrm{C}$ and $\delta^{15} \mathrm{~N}$ in tracing the food sources of animals must be inter-

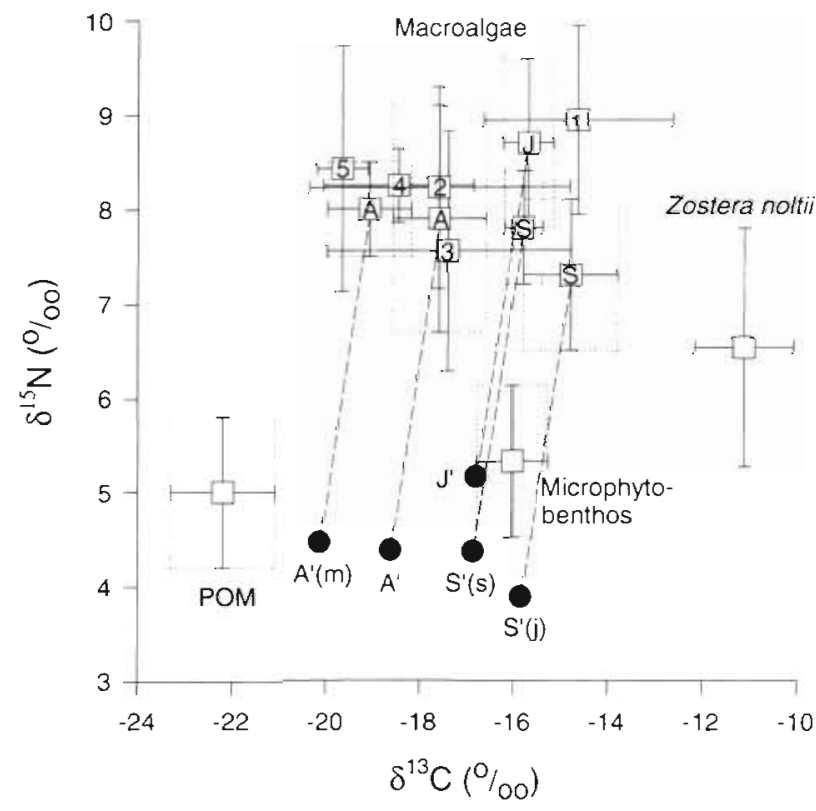

Fig. 2. Plot of $\delta^{13} \mathrm{C}$ and $\delta^{15} \mathrm{~N}$ of cockles and their potential food sources at Ronce-les-Bains (Marennes-Oléron Bay). Points and bars indicate mean $\pm 1 \mathrm{SD}$ during the sampling period. Macroalgal groups: 1, Ulva rigida; 2, Enteromorpha compressa; 3, Fucus serratus; 4, Fucus vesiculosus; 5 , Porphyra umbilicalis. $\mathrm{A}, \mathrm{J}$ and $\mathrm{S}$ : adults, juveniles and cockle spat, respectively. $A^{\prime}, J^{\prime}, S^{\prime}$ : the average $\delta^{13} \mathrm{C}$ and $\delta^{15} \mathrm{~N}$ values of their expected food source, taking trophic enrichment (-- -) into consideration. $\mathrm{m}, \mathrm{j}$ and $\mathrm{s}$ : March, June and September samples, respectively preted with caution because isotopic shifts between animals and their diets have been demonstrated. The documented enrichments per trophic level are about $1 \%$ for carbon (DeNiro \& Epstein 1978, Rau et al. 1983, Fry \& Sherr 1984) and between 3 and $4 \%$ for nitrogen (DeNiro \& Epstein 1981, Minagawa \& Wada 1984, Owens 1987). The expected $\delta^{13} \mathrm{C}$ and $\delta^{15} \mathrm{~N}$ values of food sources utilised by cockles can be estimated by subtracting these enrichments from the mean $\mathrm{C}$ and $\mathrm{N}$ isotope ratios of cockles; the dashed lines indicate the results of this procedure (Fig. 2). Consequently, the food sources would have $\delta^{13} \mathrm{C}$ and $\delta^{15} \mathrm{~N}$ values of ca $-20.1 \%$ and $4.5 \%$ for adults in March, ca $-18.6 \%$ and $4.4 \%$ for adults during the other seasons and ca $-15.5 \%$ and $4.5 \%$ for the 0 -group, respectively.

In coastal areas where macroalgae are abundant, e.g. kelp habitat, significant incorporation by bivalves of the carbon derived from macroalgal detritus has been reported (Duggins et al. 1989). In this study, there is no isotopic evidence for any important contribution of benthic macroalgae detritus to the cockle diet (Fig. 2). Although $\delta^{13} \mathrm{C}$ and $\delta^{15} \mathrm{~N}$ values for benthic macroalgae were recorded for live specimens, $\delta^{13} \mathrm{C}$ values of plants during decomposition remain similar to the initial values (Fry \& Sherr 1984, Stephenson et al. 1986, Fenton \& Ritz 1988). In contrast, Owens (1987) found increases in $\delta^{15} \mathrm{~N}$ values of plants undergoing decomposition. Wada \& Hattori (1991) also explained that during the decomposition of dead cells of marine plankton, the amount of particulate nitrogen rapidly decreased with a concomitant increase in the $\delta^{15} \mathrm{~N}$ of residual particulate matter. According to Riera et al. (1996), assimilation of carbon and nitrogen derived from different origins (for example, carbon from macroalgae and nitrogen from POM) is unlikely. Since macroalgal detritus contains relatively high amounts of nitrogen that can be readily assimilated by consumers and is ${ }^{15} \mathrm{~N}$-enriched relative to the source plant as it is degraded, the $\delta^{15} \mathrm{~N}$ values of cockles would shift toward higher values than those observed if cockles had assimilated important amounts of macroalgal detritus. In addition, the scarcity of macroalgae on the studied muddy sandflats, and more generally in the whole bay (Guillaumont 1991), suggests that they make no considerable contribution to the POM pool and to cockle growth.

Fry et al. (1987) concluded that seagrass could be an important source of organic matter in food webs of various coastal ecosystems. Although Zostera noltii in the Marennes-Oléron Bay had isotopic values distinct from those from other sources, we may exclude its potential contribution to the organic matter pool because the dense $Z$. noltii bed which had covered this flat vanished during the late 1980 s and now only a few patches $\left(<0.1 \mathrm{~m}^{2}\right)$ remain. 
Two potential food sources for cockles (algal species of POM and resuspended microphytobenthos) have similar values of $\delta^{15} \mathrm{~N}$ (Fig. 2). As previously observed in situ for other benthic invertebrates such as Patella sp., Littorina sp. and oysters Crassostrea gigas (Thunberg) by Riera (1998) and mussels Mytilus edulis L. by Minagawa \& Wada (1984), $\delta^{15} \mathrm{~N}$ values of these molluscs are 3 to $4 \%$ greater than those of their potential food sources. These results suggest that the $\delta^{15} \mathrm{~N}$ of cockles could show a significant enrichment of about 3 to $4 \%$ relative to the microalgal food sources. Thus, the dual isotope plot suggests that $C$. edule adults have the $\delta^{13} \mathrm{C}$ and $\delta^{15} \mathrm{~N}$ values expected of a mixed diet of microphytobenthos and algal POM, while juveniles and spat have values much closer to microphytobenthos. Isotopic values of cockle spat in both June and September exactly matched those of microphytobenthos (Fig. 2). These results are consistent with the observations of Ivell (1981) and Kamermans (1994) that $C$. edule utilises microphytobenthos as an available food. The contribution of microphytobenthos to estuarine food webs has long been suggested (Currin et al. 1995 and references therein).

\section{Seasonal variations in $\delta^{13} \mathrm{C}$ of adult cockle tissues}

One interesting result of this research was the seasonal variation in the $\delta^{13} \mathrm{C}$ values of adult cockles compared to more stable $\delta^{13} \mathrm{C}$ values of 0 -group cockles (Table 2, Fig. 2). These seasonal changes may result from 2 main factors. Firstly, seasonal changes in the stable isotope compositions within each food source can affect the seasonal isotopic shift of adults. Goering et al. (1990) postulated that the isotopic compositions of primary producers varied significantly with season and that these changes were rapidly reflected in the isotopic composition of some consumers (i.e. Macoma nasuta Conrad, a deposit-feeding bivalve). It seems unlikely that this factor accounts for the isotopic shifts observed in this study because there was no significant seasonal difference in the isotope compositions of POM and microphytobenthos (Table 2).

Secondly, such intraspecific variation in $\delta^{13} \mathrm{C}$ of adult cockles could be interpreted as resulting from a changing diet with season. There was a slight seasonal shift in the adult cockle tissue, with about $1.9 \%$ more negative $\delta^{13} \mathrm{C}$ values in winter, indicating assimilation of ${ }^{13} \mathrm{C}$-depleted food sources during the previous months of autumn 1994 and early winter 1995. Simenstad \& Wissmar (1985) and Riera \& Richard (1997) showed that large seasonal variation in the $\delta^{13} \mathrm{C}$ values of invertebrates was related to high freshwater discharge into estuarine sites. They pointed out a remarkable decrease of $\delta^{13} \mathrm{C}$ in both the invertebrates and the ambient POM that indicated incorporation of terrestrial organic matter during the high-flood period. According to Lazure \& Jégou (1998), the period including autumn 1994 to spring 1995 was characterised by exceptionally high water runoff of the Gironde river (peaks of freshwater discharges of between 2000 and $3800 \mathrm{~m}^{3} \mathrm{~s}^{-1}$ ). The Gironde turbid plume is known to influence shelf hydrological conditions in the Bay of Biscay, particularly those near the Pertuis de Maumusson and the Pertuis d'Antioche during western wind periods. Fontugne \& Jouanneau (1987) indicated that, in such a case, the maximal contribution of terrestrial organic matter to POM was less than $20 \%$ in the vicinity of Marennes-Oléron Bay. The higher availability of estuarine POM combined with mild temperature during the 1994-1995 winter could explain the higher ingestion and assimilation of a ${ }^{13} \mathrm{C}$-depleted diet by adult cockles. The ${ }^{13} \mathrm{C}$-depleted value of adult cockle tissue in winter could instead be explained by a lower availability of benthic microalgal food sources. Chlorophyll concentrations were very low in the water column at the end of winter 1995 (Table 1). At this time, high carbon/chlorophyll a ratios of more than 1000 were found, suggesting that much of the available carbon in the water column derives from resuspended detrital organic matter (such as oyster biodeposits). Therefore, a lower availability of microalgal biomass, a higher availability of estuarine POM in winter and, thereby, a reduction in the utilisation of the ${ }^{13} \mathrm{C}$ enriched components within the POM pool could explain the higher incorporation of ${ }^{13} \mathrm{C}$-depleted carbon into adult cockle tissue.

\section{Between-age variation in $\delta^{13} \mathrm{C}$ of cockle tissues}

A distinct seasonal variation in the $\delta^{13} \mathrm{C}$ values of adult cockles was observed between March samples and the other months, and a significant seasonal difference was noted for 0-group cockles between June (spat) and the other months (Table 2, Fig. 2). Although in the present research no decreases of $\delta^{13} \mathrm{C}$ values of POM were found with seasons, a difference in $\delta^{13} \mathrm{C}$ between adult and 0 -group cockles strongly suggests an age-related sensitivity of cockles to the availability and/or assimilation of food sources during their relative growing seasons.

The spring to early summer growth maximum for adult cockles ( $>1$ yr old) and a late summer to autumn growth for juvenile cockles, newly settled in early summer, were found in the studied flat of MarennesOléron Bay (Sauriau \& Kang unpubl.). This seasonal growth dichotomy has also been observed by Farrow (1971) in the Thames Estuary, Barnes (1973) in Southampton Water, and by Jensen (1992) in the 
Danish Wadden Sea. The availability of food can be considered a major factor regulating the growth rate of bivalves. Therefore, utilisation of different food resources by juveniles and adults during their respective non-overlapping growing seasons was proposed by Jensen (1992).

In Marennes-Oléron Bay, both phytoplanktonic and microphytobenthic blooms occur simultaneously in spring (Héral et al. 1987, Cariou-Le Gall \& Blanchard 1995). Seston dynamics are largely influenced by the resuspension of surface sediments (Héral et al. 1987 , Prou et al. 1994). Thus, resuspended benthic diatoms account for about $50 \%$ of chlorophyll $a$ in the water column at spring tide in spring and most of the chlorophyll $a$ in winter, whatever the tide (Zurburg et al. 1994). Guarini et al. (1998) also calculated that microphytobenthos supplies 30 to $90 \%$ of the chlorophyll a suspended in the water column, depending on the season. Considerable microphytobenthic biomass is still available during the summer-autumn period, when phytoplankton biomasses are very low in the water column (Cariou-Le Gall \& Blanchard 1995). Therefore, the isotopic shift between adults and juveniles may reflect seasonal variation in the availability of each microalgal source.

An alternative hypothesis would be that the isotopic shift with age (size) may be linked to the particle capture mechanism of cockles within the benthic boundary layer. Related cockle size differences in both strength of inhalant flow in response to current velocities and siphon location above the bottom are possible explanations. O'Riordan et al. (1993) showed that, under high current speed, increasing the siphon height above the bed allows bivalves to avoid refiltration (repumping) of excurrent fluid and to improve phytoplankton removal efficiency. This phenomenon could not be excluded in the case of Cerastoderma edule because adult cockles are known to stretch their short siphons up into the water in response to oxygen depletion (Jørgensen 1980). C. edule is also known to be able to actively emerge onto the surface of the sediment in response to the instability of the sandy bottom (Richardson et al. 1993). In Marennes-Oléron Bay, the study site is characterised by relatively strong current velocities (up to $0.60 \mathrm{~m} \mathrm{~s}^{-1}$ ) compared to the inhalant jet flow of adult-size cockles in the range 0.005 to $0.010 \mathrm{~m} \mathrm{~s}^{-1}$ given by André et al. (1993). We can hypothesise that adult cockles would be more effectively connected with pelagic environments than juveniles due to their potentially longer siphons and their higher pumping rates (strength of the inhalant jet, see André et al. 1993 p. 187, their Fig. 1) relative to the ambient flow conditions within the benthic boundary layer. A convergent hypothesis would be that, because resuspended matter is not uniform in size and density, particles with different settling velocities when exposed to similar shear velocities are subject to hydrodynamic sorting; denser particles such as sand grains and epipsammic diatoms bound to sand grains will be closer to the bed than lighter organic materials and epipelic diatoms as described by Muschenheim (1987).

The mechanism of selective feeding (preingestive food selection and preferential ingestion of algal components versus inorganic components) in cockles is also an important functional response to the variable food quantity and quality experienced by this species (Prins et al. 1991, Iglesias et al. 1992, Navarro et al. 1994, Navarro \& Widdows 1997). Despite a recent comparative study of feeding physiology and respiration of adult and juvenile cockles by Smaal et al. (1997), the lack of experimental evidence for a differential food selection with age makes it difficult to discuss the hypothesis of selective feeding on specific, isotopically distinct components of the POM by adult and juvenile cockles. Similarly, we can only speculate on the relative contribution of dissolved organic matter (DOM) versus POM in the nutrition of cockles at different development stages. Integumental DOM uptake is a widespread process among soft-bodied animals (Wright \& Manahan 1989). Absorption processes depend on the surface area to body volume ratio, and therefore small forms (larvae and juveniles) might have much greater physiological capacities for taking up DOM than adult forms (Manahan \& Crisp 1982). The only laboratory experiment coupling Cerastoderma edule and microphytobenthos was done by Swanberg (1991) and he indicated that $C$. edule has a stimulating effect on the growth of benthic microalgae through the release of dissolved nutrients.

The last possible explanation for the isotopic shifts between adults and juveniles is that the increase in lipid content linked to gamete production could be considered as a factor in the explanation of the $\delta^{13} \mathrm{C}$ decrease of adult cockles, since the $\delta^{13} \mathrm{C}$ value of lipids is several parts per thousand more negative than that of carbohydrate and protein (DeNiro \& Epstein 1978). In the reproduction cycle of Cerastoderma edule at Ronce-les-Bains, gametogenesis starts in winter, reproductive condition peaks from April to September, and spawning occurs mainly in June and September (Guillou et al. 1990). Our biochemical data (Kang \& Sauriau unpubl. data) also showed that the maximum gonadal development and a seasonal increase in the absolute values of lipid appeared in spring. In addition, the percent lipid content of cockle tissue does not display a significant difference between juveniles and adults and it accounts for only 6 to $12 \%$ (around 10\%) of the total tissue weight in all year classes. Similar values have been reported by Ivell (1981). This proportion would not be enough to explain the seasonal difference in the isotopic composition of adults and the 
isotopic difference of the whole bodies between juveniles and adults. Nevertheless, this explanation needs to be confirmed by examining the variation of isotope compositions with sex and gonadal stages of cockles at the same time and site.

Finally, our results suggest that food resources assimilated by cockles depend mainly on (1) their availability, which varies with season (viz. coastal and estuarine POM) and is controlled by tidal hydrodynamics (viz. resuspended microphytobenthos), (2) the timing of growth seasons of the age groups, and (3) agerelated feeding behaviour of cockles within benthic near-bed medium layers. However, it is suggested that adult cockles derive most of their diet from a mixture of resuspended microphytobenthos and suspended algal POM, whereas spat and juvenile cockles derive most of their diet from resuspended microphytobenthos. We hypothesise that utilisation of different food resources by adults and juveniles may minimise intraspecific food competition. However, the magnitude of such a process would depend on the availability of these various food resources. A comparison with other cockle populations living under different physical and trophic conditions will be necessary to validate this hypothesis in order to gain further insight into the growth strategy features exhibited by this infaunal species, as previously stated by Seed \& Brown (1978).

Acknowledgements. C.K.K. thankfully acknowledges the French Embassy, which financed a Research Grant within the framework of a co-operation program initiated between IFREMER and NRFDI, with additional financial support from CNRS. Valuable logistic and field facilities were provided by Dr Ph. Goulletquer and D. Razet from IFREMER La Tremblade. We are indebted to Dr P. Le Gall for determination of macroalgae species. We particularly thank Dr G. Cowie for his critical reading of a first draft of the manuscript. Dr T. K. Jensen, Dr S. Legall and M. Héral for fruitful discussions, and the anonymous reviewers for their valuable remarks. Thanks are due to A. Knutsen, who corrected the English.

\section{LITERATURE CITED}

André C, Jonsson PR, Lindegarth M (1993) Predation on settling bivalve larvae by benthic suspension feeders: the role of hydrodynamics and larval behaviour. Mar Ecol Prog Ser 97:183-192

Bacher C (1989) Capacité trophique du bassin de MarennesOléron couplage d'un modèle de transport particulaire et d'un modèle de croissance de l'huitre Crassostrea gigas. Aquat Living Resour 2:199-214

Barnes RSK (1973) The intertidal lamellibranches of Southampton Water, with particular reference to Cerastodarma edule and C. glaucum. Proc Malac Soc Lond 40:413-433

Berg JA, Newell RIE (1986) Temporal and spatial variations in the composition of seston available to the suspension feeder Crassostrea virginica Estuar Coast Shelf Sci 23: $375-386$
Boutton TW (1991) Stable carbon isotope ratios of natural materials: I. Sample preparation and mass spectrometric analysis. In: Coleman DC, Fry B (eds) Carbon isotope techniques. Academic Press, San Diego, p 155-171

Cariou-Le Gall V. Blanchard GF (1995) Monthly HPLC measurements of pigment concentration from an intertidal muddy sediment of Marennes-Oléron Bay, France. Mar Ecol Prog Ser 121:171-179

Cloern JE (1982) Does the benthos control phytoplankton biomass in South San Francisco Bay? Mar Ecol Prog Ser 9:191-202

Currin CA, Newell SY, Paerl HW (1995) The role of standing dead Spartina alterniflora and benthic microalgae in salt marsh food webs: considerations based on multiple stable isotope analysis. Mar Ecol Prog Ser 121:99-116

Dame RF (1996) Ecology of marine bivalves. An ecosystem approach. CRC Marine Science Series, CRC Press, Boca Raton, FL

de Jonge VN, van Beusekom JEE (1992) Contribution of resuspended microphytobenthos to total phytoplankton in the Ems estuary and its possible role for grazers. Neth J Sea Res 30:91-105

DeNiro MJ, Epstein S (1978) Influence of diet on the distribution of carbon isotopes in animals. Geochim Cosmochim Acta 42:495-506

DeNiro MJ, Epstein S (1981) Influence of diet on the distribution of nitrogen isotopes in animals. Geochim Cosmochim Acta 45:341-351

Duggins DO, Simenstad CA, Estes JA (1989) Magnification of secondary production by kelp detritus in coastal marine ecosystems. Science 245:170-173

Farrow GE (1971) Periodicity structures in the bivalve shell: experiments to establish growth controls in Cerastoderma edule from the Thames Estuary. Palaeontology 14:571-588

Fenton GE, Ritz DA (1988) Changes in carbon and hydrogen stable isotope ratios of macroalgae and seagrass during decomposition. Estuar Coast Shelf Sci 26:429-436

Feuillet-Girard M, Héral M, Abrioux MF, Fontugne M (1994) Carbone organique dissous et particulaire de la colonne d'eau et de l'interface eau-sédiment du bassin de Marennes-Oléron: influence des huîtres. Oceanol Acta 17 : $271-284$

Fontugne M, Jouanneau JM (1987) Modulation of the particulate organic carbon flux to the ocean by a macrotidal estuary: evidence from measurements of carbon isotopes in organic matter from the Gironde system. Estuar Coast Shelf Sci 24:377-387

Fry $B$, Sherr EB (1984) $\delta^{13} \mathrm{C}$ measurements as indicators of carbon flow in marine and freshwater ecosystems. Contrib Mar Sci 27:13-47

Fry B, Macko SA, Zieman JC (1987) Review of stable isotopic investigations of food webs in seagrass meadows. Florida Mar Res Publ 42:189-209

Goericke R, Montoya JP. Fry B (1994) Physiology of isotopic fractionation in algae and cyanobacteria. In: Lajtha $\mathrm{K}$, Michener RH (eds) Stable isotopes in ecology and environmental science. Blackwell Sci Publ, Oxford, p 187-221

Goering J, Alexander V, Haubenstock N (1990) Seasonal variability of stable carbon and nitrogen isotope ratios of organisms in a north Pacific bay. Estuar Coast Shelf Sci 30:239-260

Grelon M (1978) Saintonge pays des huitres vertes. Editions Rupelia, La Rochelle

Guarini JM, Blanchard GF, Bacher C, Gros P, Riera P, Richard P, Gouleau D, Galois R, Prou J, Sauriau PG (1998) Dynamics of spatial patterns of microphytobenthic biomass: inferences from a geostatistical analysis of two compre- 
hensive surveys in Marennes-Oléron Bay (France). Mar Ecol Prog Ser 166:131-141

Guillaumont B (1991) Utilisation de l'imagerie satellitaire pour les comparaisons spatiales et temporelles en zone intertidale. In: Elliott $M$, Ducrotoy JP (eds) Estuaries and coasts: spatial and temporal intercomparisons. ECSA 19 Symposium. Olsen \& Olsen, Fredensborg, p 63-68

Guillou J, Bachelet G, Desprez M, Ducrotoy JP, Madani I, Rybarczyk H, Sauriau PG, Sylvand B, Elkaim B, Glémarec $M$ (1990) Les modalités de la reproduction de la coque (Cerastoderma edule) sur le littoral français de la Manche et de l'Atlantique. Aquat Living Resour 3:29-41

Héral M, Deslous-Paoli JM. Prou J, Razet D (1987) Relations entre la nourriture disponible et la production de mollusques en milieu estuarien: variabilité temporelle de la colonne d'eau. Haliotis 16:149-158

Iglesias JIP, Navarro E, Alvarez Jorna P, Armentia I (1992) Feeding, particle selection and absorption in cockles Cerastoderma edule (L.) exposed to variable conditions of food concentration and quality. J Exp Mar Biol Ecol 162: $177-198$

Incze LS, Mayer LM, Sherr EB, Macko SA (1982) Carbon inputs to bivalve mollusks: a comparison of two estuaries. Can J Fish Aquat Sci 39:1348-1352

Ivell R (1981) A quantitative study of a Cerastoderma-Nephthys community in the Limfjord, Denmark, with special reference to production of Cerastoderma edule. $J$ Mollusc Stud 47:147-170

Jensen KT (1992) Dynamics and growth of the cockle, Cerastoderma edule, on an intertidal mud-flat in the Danish Wadden Sea: effects of submersion time and density. Neth J Sea Res 28:335-345

Jørgensen BB (1980) Seasonal oxygen depletion in the bottom waters of a Danish fjord and its effect on the benthic community. Oikos 34:68-76

Kamermans P (1994) Similarity in food source and timing of feeding in deposit- and suspension-feeding bivalves. Mar Ecol Prog Ser 104:63-75

Kerby NW, Raven JA (1985) Transport and fixation of inorganic carbon by marine algae. Adv Bot Res 11:77-123

Korringa P (1976) Farming the cupped oysters of the genus Crassostrea. Development in aquaculture and fisheries science, Vol 2. Elsevier, Amsterdam

Lazure P, Jégou AM (1998) 3D modelling of seasonal evolution of Loire and Gironde plumes on Biscay Bay continental shelf. Oceanol Acta 21:165-177

Levinton JS (1972) Stability and trophic structure in depositfeeding and suspension-feeding communities. Am Nat 106:472-486

Loo LO, Rosenberg R (1989) Bivalve suspension-feeding dynamics and benthic-pelagic coupling in an eutropicated marine bay. J Exp Mar Biol Ecol 130:253-276

Manahan DT, Crisp DJ (1982) The role of dissolved organic material in the nutrition of pelagic larvae: amino acid uptake by bivalve veligers. Am Zool 22:635-646

Mariotti A (1982) Apports de la géochimie isotopique à la connaissance du cycle de l'azote. Thèse Etat Sci, Univ Paris 6

McMillan C. Parker PL, Fry B $(1980){ }^{13} \mathrm{C} /{ }^{12} \mathrm{C}$ ratios in seagrasses. Aquat Bot 9:237-249

Michener RH, Schell DM (1994) Stable isotope ratios as tracers in marine aquatic food webs. In: Lajtha $K$, Michener RH (eds) Stable isotopes in ecology and environmental science. Blackwell Sci Publ, Oxford, p 138-157

Minagawa M, Wada E (1984) Stepwise enrichment of ${ }^{15} \mathrm{~N}$ along food chains: further evidence and the relation between $\delta^{15} \mathrm{~N}$ and animal age. Geochim Cosmochim Acta 48:1135-1140
Muschenheim DK (1987) The dynamics of near-bed seston flux and suspension-feeding benthos. J Mar Res 45: 473-496

Navarro JM, Widdows J (1997) Feeding physiology of Ceras. toderma edule in response to a wide range of seston concentrations. Mar Ecol Prog Ser 152:175-186

Navarro E, Iglesias JIP, Ortega MM (1992) Natural sediment as a food source for the cockle Cerastoderma edule (L.): eifect of variable particle concentration on feeding, digestion and the scope for growth. J Exp Mar Biol Ecol 156: 69-87

Navarro E, Iglesias JIP, Ortega MM, Larretxea X (1994) The basis for a functional response to variable food quantity and quality in cockles Cerastoderma edule (Bivalvia, Cardiidae). Physiol Zool 67:468-496

Nichols FH (1985) Increased benthic grazing: an alternative explanation for low phytoplankton biomass in northern San Francisco Bay during the 1976-1977 drought. Estuar Coast Shelf Sci 21:379-388

Officer CB, Smayda TJ, Mann R (1982) Benthic filter feeding: a natural eutrophication control. Mar Ecol Prog Ser 9:203-210

O'Riordan CA, Monismith SG, Koseff JR (1993) A study of concentration boundary-layer formation over a bed of model bivalves. Limnol Oceanogr 38:1712-1729

Owens NJP (1987) Natural variations in ${ }^{15} \mathrm{~N}$ in the marine environment. In: Blaxter JHS, Southward AJ (eds) Advances in marine biology, Vol 24. Academic Press, London, p $389-451$

Papy L (1941) La côte atlantique de la Loire à la Gironde. Delmas, Bordeaux

Peterson BJ, Howarth RW (1987) Sulfur, carbon, and nitrogen isotopes used to trace organic matter flow in the saltmarsh estuaries of Sapelo Island, Georgia. Limnol Oceanogr 32:1195-1213

Prins TC, Smaal AC, Pouwer AJ (1991) Selective ingestion of phytoplankton by the bivalves Mytilus edulis L. and Cerastoderma edule (L.). Hydrobiol Bull 25:93-100

Prou J, Barillé L, Héral M, Ratiskol G, Soletchink P, Bougrier S, Razet D, Geairon P (1994) Influence du cycle semidiurne et vives-eaux mortes-eaux sur la disponibilité du matériel particulaire et son utilisation par une population de Mytilus edulis. Haliotis 23:139-153

Purchon RD (1977) The biology of the mollusca Pergamon Press, Oxford

Rau GH, Mearns AJ, Young DR, Olson RJ, Schafer HA, Kaplan IR (1983) Animal ${ }^{13} \mathrm{C} /{ }^{12} \mathrm{C}$ correlates with trophic level in pelagic food webs. Ecology 64:1314-1318

Raillard O, Ménesguen A (1994) An ecosystem box model for estimating the carrying capacity of a macrotidal shellfish system. Mar Ecol Prog Ser 115:117-130

Richard P, Riera P, Galois R (1997) Temporal variations in the chemical and carbon isotope compositions of marine and terrestrial organic inputs in the Bay of Marennes-Oléron, France. J Coastal Res 13:879-889

Richardson CA, Ibarrola I, Ingham RJ (1993) Emergence pattern and spatial distribution of the common cockle Cerastoderma edule. Mar Ecol Prog Ser 99:71-81

Riera $\mathrm{P}(1998) \delta^{15} \mathrm{~N}$ of organic matter sources and benthic invertebrates along an estuarine gradient in MarennesOléron Bay (France): implications for the study of trophic structure. Mar Ecol Prog Ser 166:143-150

Riera P, Richard P (1996) Isotopic determination of food sources of Crassostrea gigas along a trophic gradient in the estuarine Bay of Marennes-Oléron. Estuar Coast Shelf Sci $42: 347-360$

Riera P, Richard P (1997) Temporal variation of $\delta^{13} \mathrm{C}$ in particulate organic matter and oyster Crassostrea gigas in 
Marennes-Oléron Bay (France) : effect of freshwater inflow. Mar Ecol Prog Ser 147:105-115

Riera P, Richard P, Grémare A, Blanchard G (1996) Food source of intertidal nematodes in the Bay of MarennesOléron (France), as determined by dual stable isotope analysis. Mar Ecol Prog Ser 142:303-309

Sauriau PG, Mouret V, Rincé JP (1989) Organisation trophique de lá malacofaune benthique non cultivée du bassin ostréicole de Marennes-Oléron. Oceanol Acta 12:193-204

Schwinghamer P, Tan FC, Gordon DC Jr (1983) Stable carbon isotope studies on the Pecks Cove mudflat ecosystem in the Cumberland Basin, Bay of Fundy. Can J Fish Aquat Sci 40(Suppl 1):262-272

Seed R, Brown RA (1978) Growth as a strategy for survival in two marine bivalves, Cerastoderma edule and Modiolus modiolus. J Anim Ecol 47:283-292

Siegel S (1956) Nonparametric statistics for the behavioral sciences. McGraw-Hill New York

Simenstad CA. Wissmar RC $(1985) \delta^{13} \mathrm{C}$ evidence of the origins and fates of organic carbon in estuarine and nearshore food webs. Mar Ecol Prog Ser 22:141-152

Smaal AC, Vonck APMA. Bakker M (1997) Seasonal variation

Editorial responsibility: Otto Kinne (Editor).

Oldendorf/Luhe, Germany in physiological energetics of Mytilus edulis and Cerastoderma edule of different size classes. J Mar Biol Assoc UK $77: 817-838$

Sokal R, Rohlf FJ (1981) Biometry, 2nd edn. WH Freeman \& Co, New York

Stephenson RL, Lyon GL (1982) Carbon-13 depletion in an estuarine bivalve: detection of marine and terrestrial food sources. Oecologia 55:110-113

Stephenson RL, Tan FC, Mann KH (1986) Use of stable carbon isotope ratios to compare plant material and potential consumers in a seagrass bed and a kelp bed in Nova Scotia, Canada. Mar Ecol Prog Ser 30:1-7

Swanberg IL (1991) The influence of the filter-feeding bivalve Cerastoderma edule L. on microphytobenthos: a laboratory study. J Exp Mar Biol Ecol 151:93-111

Wada E, Hattori A (1991) Nitrogen in the sea: forms, abundances, and rate processes. CRC Press, Boca Raton, FL

Wright SH, Manahan DT (1989) Integumental nutrient uptake by aquatic organisms. Annu Rev Physiol 51:585-600

Zurburg W, Smaal AAD, Héral M, Danker N (1994) Seston dynamics and bivalve feeding in the Bay of MarennesOléron (France). Neth J Aquat Ecol 28:459-466

Submitted: November 6, 1998; Accepted: April 9, 1999

Proofs received from author(s): September 27, 1999 